\title{
The Effect of Ductoscopy in the Surgical Selection of Patients with Pathological Nipple Discharge
}

\author{
- Kenan Çetin
}

Department of General Surgery, University of Health Sciences, Kartal Dr. Lütfi Kırdar Training and Research Hospital, İstanbul, Turkey

Submitted: 11.09.2018 Accepted: 01.11.2018

Correspondence: Kenan Çetin Kartal Dr. Lütfi Kırdar Eğitim ve Araştırma Hastanesi, Genel Cerrahi Kliniği, İstanbul, Turkey E-mail:drkenancetin@hotmail.com

Keywords: Ductoscopy; pathological nipple discharge; selection of surgery.

\begin{abstract}
Objective: Surgical excision of the ductus is the current conventional means of treatment and diagnosis of pathological nipple discharge (PND). However, a review of the histopathology results of cases of routine duct excision reveals that a large number of unnecessary surgical interventions are performed. The aim of this study was to determine the rate of lesion detection after a ductoscopic evaluation in patients who underwent surgery.
\end{abstract}

Methods: Between November 2005 and December 2010, a microductectomy was performed following a ductoscopic evaluation for 129 patients who were admitted to our clinic with PND. The characteristics of the discharge, and the ductoscopic and pathological findings were assessed.

Results: The final pathology results confirmed lesions in $76 \%$ of the patients $(85 / 1 / 2)$ who underwent surgery based on only ductoscopic findings. Seventeen patients with ductoscopic findings who were operated on based on the findings of a physical examination and classical imaging methods could be followed up. Lesions were detected in II (6 potential neoplastic and malignant lesions, 5 papillomatous lesions).

Conclusion: The results of this study indicate that ductoscopy appears to predict the patients who will require surgical treatment and so can decrease the number of operations. However, conventional imaging and physical examination findings of patients should also be considered in the follow-up after ductoscopy in PND patients.

\section{INTRODUCTION}

Intermittent or continuous nipple discharge is the third most frequent (up to 10\%) reason for women to present at medical facilities with complaints of the breast after breast pain and mass. The reason for most nipple discharge is physiological. ${ }^{[1,2]}$ Pathological nipple discharge (PND) is described as spontaneous, unilateral, hemorrhagic, serohemorrhagic, and serous exudate from a single duct apart from pregnancy and lactation. ${ }^{[3-5]}$ The most common cause of nipple discharge is a benign breast lesion, such as a solitary intraductal papilloma or papillomatosis..$^{[6]}$ However, an important cause of PND is breast cancer, which constitutes between $5 \%$ and $21 \%$ of cases. ${ }^{[6,7]}$

Imaging methods play an essential role in the diagnostic approach to PND, following complete anamnesis and physical examination. The classical modalities preferred are mammography, ultrasonography (USG), magnetic resonance imaging (MRI), cytology of discharge smear, fine-needle aspiration biopsy, and core biopsy. Mammography and USG have a low sensitivity for detecting small intraductal lesions. ${ }^{[8]}$ MRI may not always be successful in determining all intraductal neoplasms. ${ }^{[9,10]}$

Galactography offers an indirect view of the milk ducts, while ductoscopy can provide direct visualization. The combined use of these imaging modalities may increase the reliability of the diagnosis, but may nonetheless be inadequate. Therefore, the general approach used to create a definitive diagnosis for women with PND is ductal excision. ${ }^{[1,12]}$ Although it has not yet been accepted all over the world, the recognition of the value of breast ductoscopy is increasing worldwide as a new method that can help to investigate nipple discharge..$^{[13,14]}$

Ductoscopy is the use of an endoscope to image breast milk ducts in patients with nipple discharge. It provides a direct view of the inside of the ducts and it is possible to evaluate and locate epithelial abnormalities and lesions. In addition, intraductal polypoid lesions can be excised endoscopically through the working channel of the endoscope. ${ }^{[15]}$ Although ductoscopy is currently performed in a limited number of centers, a consensus has not yet been reached concerning interpretation of the findings. ${ }^{[16,1]]}$ 
Studies are underway to evaluate its place in the diagnosis and treatment nipple discharge.

The aim of this study was to retrospectively compare the results of ductectomy and postoperative surgical pathology results in patients whose indication for surgical treatment was based on preoperative examination, conventional imaging, and ductoscopy findings.

\section{MATERIAL AND METHODS}

Between November 2005 and December 2010, 129 patients with nipple discharge who underwent a ductectomy and an isolated ductal excision performed by the general surgery department of the Okmeydanı Training and Research Hospital were included in the study. The nipple discharge characteristics of the patients, the ductoscopic findings and demographic details were retrospectively obtained and analyzed. The study protocol was approved by the Okmeydanı Training and Research Hospital's ethics committee, and all patients provided written informed consent before ductoscopy and surgery.

The standard approach in patients with at least 2 criteria of PND was a complete mammography (though not preferred in patients under 40 years of age) followed by a physical examination, breast ultrasonography, ductoscopy, and ductal lavage cytology. Patients with only a single criterion of PND were evaluated with a physical examination and conventional imaging.

Patients with no significant findings from the ductoscopy and normal physical examination, conventional imaging and lavage cytology results in terms of intraductal lesion are routinely followed up in our clinic. Surgical intervention is recommended for all other patients (i.e., for those with positive ductoscopic findings and/or suspect physical examination, conventional imaging or cytology findings with persistent nipple discharge).

The ductoscopic images were evaluated according to findings of a normal appearance, changes in ductal calibration (ductal stenosis or ectasia), intraluminal secretion or debris, lesion, ductal epithelial color changes, irregular intraluminal mass, ductal wall irregularities, solitary papilloma (SP), or multiple papillomas (MP). Based on the pathology results, lesions were classified as papillomatous lesions, atypical ductal hyperplasia (ADH), ductal carcinoma in situ (DCIS), invasive carcinoma potential neoplastic and malignant lesions (PNML), SP, or MP.

\section{Ductoscopy procedure}

Prior to ductoscopy, the areola was cleansed with a disinfectant ( $10 \%$ polyvinylpyrrolidone iodine solution) and I cc local anesthetic ( $2 \%$ prilocaine) was applied around the nipple to ensure minimal discomfort. A 55-mm diameter, single-channel (irrigation channel) 3000 pixel LaDuScope-S and a $1.1-\mathrm{mm}$ diameter, dual channel (working and irrigation channels), 6000 pixel LaDuScope-T flex (Polydiagnost $\mathrm{GmbH}$, Pfaffenhofen, Germany) optical system were used

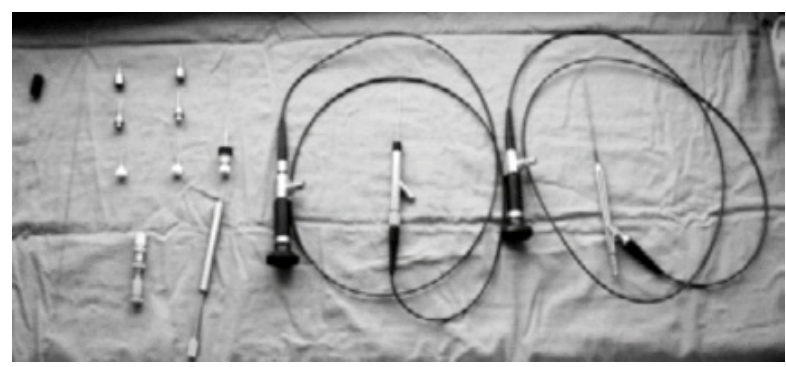

Figure 1. LaDuScope S-flex (0.55 mm), LaDuScope T-flex (1.1 $\mathrm{mm}$ ) (Polydiagnost $\mathrm{GmbH}$, Pfaffenhofen, Germany), dilator bougies, and shafts.

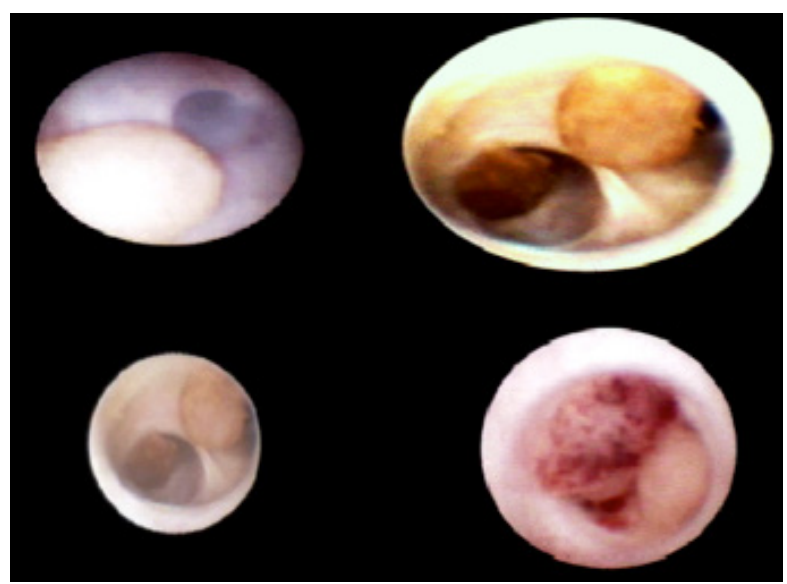

Figure 2. Ductoscopic images of intraductal papillomas.

to perform the ductectomy (Fig. I). The sphincter of the duct with discharge was dilated with the aid of the dilator bougies and the shaft of the ductoscope was positioned.

The ductoscope was passed through the prepared shaft. The single-channel scope was used initially to provide the intraductal image. When a papillomatous structure (Fig. 2), intraluminal irregular mass, ductal wall irregularity, or epithelial discoloration was observed and surgical intervention was required, the ductoscope with a working channel was used. A 2-0 Prolene suture (Ethicon, Inc., Somerville, $\mathrm{NJ}$, USA) was advanced to the lesion through the working channel of the ductoscope, and the duct to be excised was marked. After removing the ductoscope from the channel, the areola was closed with a square sponge to ensure that the suture remained in the duct, and the four sides of the sponge were taped. This procedure was performed within 2 days. Dilatation of the working channel and insertion of the ductoscope into the working channel were the most difficult stages of the ductoscopy.

\section{Microductectomy procedure}

The operations were performed under general anesthesia in operating room conditions. A blue-tipped angiocath was advanced over Prolene suture material into the duct, the labeled suture was removed from the lesioned area, and approximately $\mathrm{I}-2 \mathrm{cc}$ of methylene blue was delivered to the lesioned area using an angiocath. Afterward, the main duct, stained blue through a periareolar incision, was iso- 

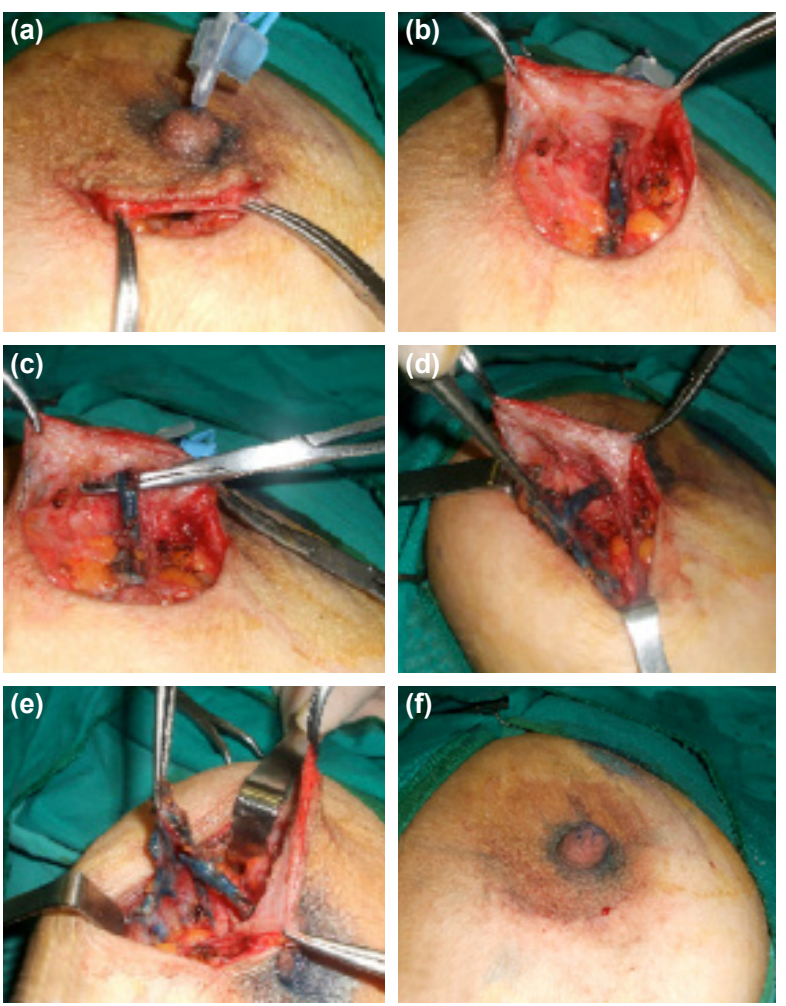

Figure 3. (a-d) Microductectomy procedure.

lated with its branches as distally as possible and excised (Fig. 3).

\section{Statistical analysis}

In this study, the pathology results were accepted as optimal method of determining the etiology of the nipple discharge. SPSS for Windows, Version 15.0 (SPSS Inc., Chicago, IL, USA) was used to perform statistical calcula- tions. Chi-square tests and Pearson correlation coefficient techniques were used in the statistical analysis. $P \leq 0.05$ was considered statistically significant.

\section{RESULTS}

The age range of the patients was 17 to 76 years (mean: $41.3 \pm 11.8$ years). Among the operated patients, 77 (59.7\%) women were of reproductive age and 52 (40.3\%) were menopausal. In $74.4 \%$ (96/I29) of the patients, lesions (papillary lesions+PNML) were detected. PNML was seen in $21 \%(27 / 129)$ of the patients without color separation and in $21.2 \%(25 / \mathrm{I} / 8)$, hemorrhagic or serohemorrhagic discharge was observed. Lesions were confirmed in 8 of II patients who did not comply with the colors described in the PND criteria (hemorrhagic, serohemorrhagic, and serous) (Table I). Lesions were determined in $70.8 \%$ (75/I06) of PND3+, and in $91.3 \%$ (2I/23) of PND2+ patients. PNML was detected in $20.7 \%(22 / 106)$ of PND3+ and $21.7 \%(5 / 23)$ of PND2+ patients ( $>>0.05$ ) (Table 2).

The data obtained from the comparison of the ductoscopic findings with the pathology results $(n=129)$ were as follows:

Of the 17 patients whose ductoscopy was evaluated as normal, ductalectasia, or intraluminal secretion, 12 underwent surgery due to the presence of an intraductal lesion, 4 for persistent discharge after ductoscopy, and I for a palpable mass. Postoperative histopathology reports confirmed the presence of PNML in 6 (35.3\%) of the II (64.7\%) patients in this group that could be followed-up (Table 3).

A ductal excision was performed for 112 patients whose ductoscopy was evaluated as positive for intraductal lesions (intraluminal irregular mass: $n=7$; $S P$ : $n=41$; MP: $n=28$ ), suspect (ductal epithelial discoloration: $n=10$; duc-

Table I. Histopathology results based on the color of the discharge $(n=129)$

\begin{tabular}{|c|c|c|c|c|c|c|c|c|c|}
\hline Color of the discharge & SP & MP & Debris & Mastitis & DCIS & $\begin{array}{l}\text { Invasive } \\
\text { carcinoma }\end{array}$ & ADH & $\begin{array}{c}\text { Ductal } \\
\text { hyperplasia }\end{array}$ & $\begin{array}{l}\text { Ductal } \\
\text { ectasia }\end{array}$ \\
\hline Hemorrhagic (72) & 20 & 18 & & 8 & 5 & 7 & 3 & 7 & 4 \\
\hline Serohemorrhagic (46) & 13 & 12 & I & 6 & 5 & 3 & 2 & 2 & 2 \\
\hline Milky (3) & I & 2 & & & & & & & \\
\hline Other (8) & 2 & I & & 2 & I & & I & I & \\
\hline
\end{tabular}

ADH: Atypical ductal hyperplasia; DCIS: Ductal carcinoma in situ; MP: Multiple papillomas; SP: Solitary papilloma.

Table 2. Histopathology results based on PND criteria $(n=129)$

\begin{tabular}{|c|c|c|c|c|c|c|c|c|c|c|c|}
\hline $\begin{array}{l}\text { Number of PND } \\
\text { criteria }\end{array}$ & $\begin{array}{c}S P \\
(36)\end{array}$ & $\begin{array}{l}\text { MP } \\
\text { (33) }\end{array}$ & $\begin{array}{l}\text { Debris } \\
\text { (I) }\end{array}$ & $\begin{array}{c}\text { Mastitis } \\
\text { (16) }\end{array}$ & $\begin{array}{l}\text { DCIS } \\
\text { (II) }\end{array}$ & $\begin{array}{l}\text { Invasive } \\
\text { carcinoma } \\
\text { (10) }\end{array}$ & $\begin{array}{c}\text { ADH } \\
(6)\end{array}$ & $\begin{array}{c}\text { Ductal } \\
\text { hyperplasia } \\
\text { (10) }\end{array}$ & $\begin{array}{c}\text { Ductal } \\
\text { ectasia } \\
(6)\end{array}$ & $\begin{array}{c}\text { Cases with } \\
\text { lesions } \\
\text { n (\%) }\end{array}$ & $\begin{array}{l}\text { PNML } \\
\text { n (\%) }\end{array}$ \\
\hline PND 2+ $(n=23)$ & II & 5 & I & 5 & 3 & 0 & 2 & 1 & 0 & 21 (9I.3) & $5(2 \mid .7)$ \\
\hline PND $3+(n=106)$ & 25 & 28 & 0 & II & 8 & 10 & 4 & 9 & 6 & $75(70.8)$ & $22(20.7)$ \\
\hline
\end{tabular}

ADH: Atypical ductal hyperplasia; DCIS: Ductal carcinoma in situ; MP: Multiple papillomas; PND: Pathological nipple discharge; PNML: Potential neoplastic and malignant lesions; SP: Solitary papilloma. 
Table 3. Surgical indications in patients and final histopathology results

\begin{tabular}{|c|c|c|c|c|c|c|c|c|c|c|c|}
\hline Ductoscopy findings & Surgical indications & $\begin{array}{l}S P \\
(36)\end{array}$ & $\begin{array}{l}\text { MP } \\
\text { (33) }\end{array}$ & $\begin{array}{l}\text { Debris } \\
\text { (I) }\end{array}$ & $\begin{array}{l}\text { Mastitis } \\
(16)\end{array}$ & $\begin{array}{l}\text { DCIS } \\
\text { (II) }\end{array}$ & $\begin{array}{c}\text { Invasive } \\
\text { carcinoma } \\
(10)\end{array}$ & $\begin{array}{l}\text { ADH } \\
\text { (6) }\end{array}$ & $\begin{array}{c}\text { Ductal } \\
\text { hyperplasia } \\
\text { (10) }\end{array}$ & $\begin{array}{c}\text { Ductal } \\
\text { ectasia } \\
\text { (6) }\end{array}$ & Tota \\
\hline \multirow[t]{2}{*}{ Normal (2) } & Radiological indication & & & & & & & I & & & 1 \\
\hline & Persistent discharge & & & & & & & & & I & 1 \\
\hline Changes in ductal & Radiological indication & 3 & I & & & I & 2 & & & & 7 \\
\hline calibration (8) & Palpable mass on examination & & & & & & I & & & & 1 \\
\hline Intraluminal secretion/ & Radiological indication & & & I & I & & I & & I & & 4 \\
\hline debris $(7)$ & Persistent discharge & & I & & I & & & & & I & 3 \\
\hline Epithelial discoloration & Discoloration of ductal wall & & & & 3 & I & & I & 3 & I & 9 \\
\hline$(10)$ & + Suspect cytology & & & & & & & I & & & 1 \\
\hline $\begin{array}{l}\text { Intraluminal irregular } \\
\text { mass }(7)\end{array}$ & Irregular appearance & I & I & & I & I & I & & I & I & 7 \\
\hline Ductal wall irregularity & Ductal wall irregularity & I & 4 & & 5 & 5 & 3 & 1 & 4 & 2 & 25 \\
\hline (26) & + Suspect cytology & & & & & I & & & & & 1 \\
\hline Solitary papilloma (4I) & Solitary papilloma & 31 & 7 & & I & I & & I & & & 41 \\
\hline Multiple papillomas (28) & Multiple papillomas & & 19 & & 4 & I & 2 & I & I & & 28 \\
\hline
\end{tabular}

ADH: Atypical ductal hyperplasia; DCIS: Ductal carcinoma in situ; MP: Multiple papillomas; SP: Solitary papilloma.

tal wall irregularities: $n=26$ ), and lesions were confirmed with histopathology results in 85 (76\%). PNML was detected in 3 of 10 patients with epithelial discoloration, 2 of 7 cases with irregular intraluminal mass lesions, and in 10 of 26 cases with ductal wall irregularities. In other words, $35 \%$ (15/43) of cases with PNML were confirmed pathologically. The PMNL rate was lower in the other lesion groups (14\%, 12/86; $\mathrm{p}=0.006)$ (Table 3).

One patient developed mastitis requiring oral antibiotic treatment for one week after the ductoscopy. No complication was observed in any patient after the microductectomy.

\section{DISCUSSION}

Spontaneous, unilateral, hemorrhagic, or serous discharge from a single duct, excluding conditions of pregnancy and lactation defines PND. ${ }^{[3]}$ The most common causes of PND are benign breast lesions, such as solitary intraductal papilloma and papillomatosis (35-48\%), but it can be a sign of malignancy in rare cases. ${ }^{[4]}$ For this reason, surgeons should evaluate the complaints and symptoms of these patients very carefully.

The literature provides a description to be used to distinguish PND from physiological discharge, but there is no consensus about for whom ductoscopy should be performed. In our clinic, we perform ductoscopy in patients who have at least 2 of these criteria (spontaneous, single duct, hemorrhagic/serous discharge). Ductoscopy resulted in the determination of a lesion in $74.4 \%$ (96/129) of the patients. The literature offers a comparable detection rate of between $36 \%$ and $81 \% .^{[18]}$ When we classified PND cases based on predefined criteria, our lesion detection rate was $91.3 \%$ in PND2+ and $70.8 \%$ in patients with PND3+. Our higher rate of lesion detection rate in PND2+ cases may have been due to the fact that ductal excision for PND2+ patients is viewed as more difficult, while PND3+ cases are considered more straightforward. We elect to perform surgery if the findings of a physical examination and conventional imaging methods support the presence of a lesion.

The rate of PNML has been reported as $7 \%$ in the literature, if the color of the discharge is not taken into consideration. If there is bloody discharge, the rate increases to $31 \% .{ }^{[19]}$ In our study, we found PNML in $21 \%(27 / 129)$ of the total patient group in this study. Among the PND3+ patients the rate observed was $20.7 \%$, and it was $21.7 \%$ in the PND2+ group ( $p>0.05)$.

In the literature, the sensitivity of smear cytology made from nipple discharge has been reported as $16 \%$ to $40 \%$. $[19,20]$ This may be helpful in diagnosis, but cannot distinguish between ADH, intraductal papilloma, and DCIS. ${ }^{[21]}$ In the last 20 years, ductoscopy has begun to be used to help make this distinction. The rigid ductoscopies that were initially used have been replaced with semi-flexible endoscopes with a working channel and the capability to yield high-resolution images and taking a biopsy from the lesion. $[22,23]$ These developments have reduced the technical difficulties of ductoscopy and provided an easily applicable procedure. Now, it is possible to perform a ductoscopy with minimal risk and complications in the course of outpatient diagnosis and treatment. ${ }^{[24]}$

Of the patients in this study with suspicious findings (color changes in wall epithelium, irregular intraluminal mass, wall irregularities, or intraductal lesion), we found a false positivity rate of $24.1 \%(27 / 1 / 2)$. Assessment of the subgroup of patients with discoloration of the wall epithelium revealed a rate of false positivity of $70 \%(7 / 10)$, while it was $42.3 \%(1 / / 26)$ among those with wall irregularities. This is likely due to the presence of mastitis $(n=8)$ and ductal hyperplasia $(n=7)$. Both pathologies can cause structural changes and discoloration of the duct wall. We believe that this confusion can be overcome using higher resolu- 
tion endoscopes that will be developed in the future.

We determined a false negativity rate of $64.7 \%$ (II/I7) in patients whose ductoscopy was evaluated as non-suspicious (normal, ductal calibration change, intraluminal secretion/debris findings), but for whom surgery was performed as a result of the physical examination $(n=I)$, conventional imaging findings $(n=12)$, or persistent discharge $(n=4)$. We attributed this high rate of false negativity to our exclusion of patients for whom we decided to follow-up without surgery based on the ductoscopy findings. Nonetheless, these data indicated that ductoscopy alone cannot exclude the possibility of lesions in patients with persistent PND or suspect findings detected using conventional imaging and physical examinations.

As with every method, there are some technical limitations to the ductoscopy. There are approximately I5 to 30 main breast ducts opening into each nipple. ${ }^{[25]}$ It is impossible to access each ductolobular area and obtain images during ductoscopy. It is also highly dependent on the experience and ability of the ductoscopist and there is a learning curve to achieving expertise in the technique. Possible complications of the procedure include pain, inflammation, and infection; however, they are rarely seen. In our study, only I patient had mastitis, which was limited to the breast skin and responded to antibiotics within a short time.

\section{CONCLUSION}

The findings of this study suggest that ductoscopy is a good predictor both in determining the patients who need surgical treatment and in reducing the number of unnecessary surgical procedures. Combined use with ductal lavage and classic imaging modalities may help to detect malignant cases during an early stage of disease. Therefore, patients with at least 2 criteria of PND should be evaluated with ductoscopy. Conventional imaging and physical examination findings should be taken into consideration for postductoscopy follow-up plans. Ductoscopy is a candidate to be the gold standard in the diagnosis and treatment of patients with PND.

Ethics Committee Approval

Approved by the Okmeydanı Training and Research Hospital's ethics committee.

Informed Consent

All patients provided written informed consent before ductoscopy and surgery.

Peer-review

Internally peer-reviewed.

Authorship Contributions

Concept: K.Ç.; Design: K.Ç.; Data collection \&/or processing: K.Ç.; Analysis and/or interpretation: K.Ç.; Literature search: K.Ç.; Writing: K.Ç.; Critical review: K.Ç.

Conflict of Interest

None declared.

\section{REFERENCES}

1. Gioffre Florio M, Manganero T, Pollicino A, Scarfo P, Micali B. Surgical approach to nipple discharge: a ten year experience. J Surg Oncol 1999;71:235-8. [CrossRef]

2. Leis HP, Grene FL, Cammarata A, Hilfer SE. Nipple discharge: surgical significance. South Med J 1998;81:22-5.

3. Klimberg VS. Nipple Discharge: More Than Pathologic. Ann Surg Oncol 2003;10:98-9. [CrossRef]

4. Cabioglu N, Hunt KK, Singletary SA, Stephens TW, Marcy S, Meric $\mathrm{F}$, et al. Surgical decision making and factors determining a diagnosis of breast carcinoma in women presenting with nipple discharge. J Am Coll Surg 2003;196:354-64. [CrossRef]

5. Hussain AN, Policarpio C, Vincent MT. Evaluating nipple discharge. Obstet Gynecol Surv 2006;61:278-83. [CrossRef]

6. Vargas HI, Vargas MP, Eldrageely K, Gonzales KD, Khalkhali I. Outcomes of clinical and surgical assessment of women with pathological nipple discharge. Am Surg 2006;72:124-8.

7. Goksel HA, Yagmurdur MC, Demirhan B, Isiklar I, Karakayali H, Bilgin N, et al. Management strategies for patients with nipple discharge. Langenbecks Arch Surg 2005;390:52-8. [CrossRef]

8. Matsunaga T, Misaga T, Hosokawa K, Taira S, Kim K, Serizawa H, et al. Intraductal approach to the detection of intraductal lesions of the breast. Breast Cancer Res Treat 2009;118:9-13. [CrossRef]

9. Morrogh M, Morris EA, Liberman L, Borgen PI, King TA. The predictive value of ductography and magnetic resonance imaging in the management of nipple discharge. Ann Surg Oncol 2007;14:3369-77.

10. Kapenhas-Valdes E, Feldman SM, Cohen JM, Boolbol SK. Mammary ductoscopy for evaluation of nipple discharge. Ann Surg Oncol 2008;15:2720-7. [CrossRef]

11. Dawes LG, Bowen C, Venta LA, Morrow M. Ductography for nipple discharge: no replacement for ductal excision. Surgery 1998;124:685-91. [CrossRef]

12. Simmons R, Adamovich T, Brennan M, Christos P, Schultz M, Eisen C, et al. Nonsurgical evaluation of pathologic nipple discharge. Ann Surg Oncol 2003;10:113-6. [CrossRef]

13. Dietz JR, Crowe JP, Grundfest S, Arrigain S, Kim JA. Directed duct excision by using mammary ductoscopy in patients with pathologic nipple discharge. Surgery 2002;132:582-7. [CrossRef]

14. Sharma R, Dietz J, Wright H, Crowe J, DiNunzio A, Woletz J, et al. Comparative analysis of minimally invasive microductectomy versus major duct excision in patients with pathologic nipple discharge. Surgery 2005;138:591-6. [CrossRef]

15. Matsunaga T, Ohta D, Misaka T, Hosokawa K, Fujii M, Kaise H, et al. Mammary ductoscopy for diagnosis and treatment of intraductal lesions of the breast. Breast Cancer 2001;8:213-21. [CrossRef]

16. Makita M, Sakamoto G, Akiyama F, Namba K, Sugano H, Kasumi F, et al. Duct endoscopy and endoscopic biopsy in the evaluation of nipple discharge. Breast Cancer Res Treat 1991;18:179-88. [CrossRef]

17. Love SM, Lawler MJ. Breast duct endoscopy: a pilot study of a potential technique for evaluating intraductal disease. Breast Cancer Res Treat 1992;23:180.

18. Grunwald S, Heyer H, Paepke S, Schwesinger G, Schimming A, Hahn M, et al. Diagnostic value of ductoscopy in the diagnosis of nipple discharge and intraductal proliferations in comparison to standard methods. Oncologie 2007;30:243-8.

19. Al Sarakbi W, Salhab M, Mokbel K. Does mammary ductoscopy have a role in clinical practice? Int Semin Surg Oncol 2006;3:16. [CrossRef]

20. Carvalho MJ, Dias M, Gonçalo M, Fernandes G, Rodriues V, de Oliveira CF. What is the diagnostic value of nipple discharge cytology and galactography in detecting duct pathology? Eur J Gynaecol Oncol 2009;30:543-6. 
21. Tang SS, Twelves DJ, Isacke CM, Gui GP. Mammary ductoscopy in the current management of breaswt disease. Surg Endosc 2011:25:1712-22. [CrossRef]

22. Berna JD, Gracia-Medina V, Kuni CC. Ductoscopy: A new technique for ductal exploration. Eur J Radiol 1991;12:127-9. [CrossRef]

23. Okazaki A, Okazaki M, Asaishi K, Satoh H, Watanbe Y, Mikami T, et al. Fiberoptik doctoscopy of the breast: a new diagnostic procedure for nipple discharge. Jpn J Clin Oncol 1991;18:188-93.

24. Khan SA, Mangat A, Rivers A, Revesz E, Susnik B, Hanse N. Office ductoscopy for surgical selection in women with pathologic nipple discharge. Ann Surg Oncol 2011;18:3785-90. [CrossRef]

25. Rubley JE, Brachtel EF, Michaelson JS, Koerner FC, Smith BL. Breast duct anatomy in the human nipple: three-dimensional patterns and clinical applications. Breast Cancer Res Treat 2007;106:171-9. [CrossRef]

\section{Patolojik Meme Başı Akıntıı Hastaların Cerrahi Seçiminde Duktoskopinin Etkisi}

Amaç: Günümüzde patolojik meme başı akıntısının (PMA) konvansiyonel tanı ve tedavisi cerrahi duktus eksizyonudur. Rutin duktus eksizyonu uygulanan olguların patoloji sonuçları incelendiğinde yüksek oranda gereksiz cerrahi girişim yapıldığı ortaya çımaktadır. Bu çalışmada amacımız duktoskopik değerlendirme sonrası cerrahi yapılan hastalarda lezyon saptama oranlarını belirlemektir.

Gereç ve Yöntem: Kasım 2005-Aralık 2010 tarihleri arasında PMA ile meme polikliniğine başvuran ve ofis ortamında yapılan duktoskopileri sonucu operasyon kararı verilen 129 hataya izole duktus eksizyonu uygulandı. Hastaların akıntı karakterleri, duktoskopi bulguları ve patoloji sonuçları karşılaştırıldı.

Bulgular: Sadece duktoskopik bulgular ile cerrahi kararı verilen hastaların \%76'sında (85/I I2) lezyonlar nihai patoloji sonuçları ile doğrulandı. Duktoskopi bulguları ile tekip kararı verilebilecek 17 hasta fizik muayene ve klasik görüntüleme yötemlerindeki bulguları nedeni ile ameliyat edildi ve bunların II'inde (\%64.7) lezyon saptandı (6'sı PNML, 5'i papillamatöz).

Sonuç: Çalışmamızın bulguları, duktoskopinin cerrahi tedavi gereken hastaları belirlemede iyi bir öngörücü olduğunu göstermektedir. Ancak PMA'ı hastalarda duktoskopi sonrası takip kararı verilirken hastaların konvansiyonel görüntüleme ile fizik muayene bulguları da göz önünde bulundurulmalıdır.

Anahtar Sözcükler: Cerrahi seçim; duktoskopi; patolojik meme başı akıntısı. 